\title{
Primary bone tumors and tumor-like lesions of the radius operated in a tertiary orthopedic oncology center
}

\section{Üçüncü basamak bir ortopedik onkoloji merkezinde opere edilen radius primer kemik tümörleri ve tümör benzeri lezyonlar}

\author{
Omer SOFULU*
}

Marmara University, Faculty of Medicine, Department of Orthopaedic Surgery and Traumatology, Istanbul/ TURKEY

\begin{abstract}
Aim: This study aimed to evaluate the incidence, surgical management, histologic and anatomic distribution of patients who operated in a tertiary orthopedic oncology center with diagnosing primary bone tumors of the radius.

Material and Methods: A total of 96 patients ( 37 female, 59 male ) who presented to our department in the period of 17 years (2003-2020) with the diagnosis of bone tumors of radius were analyzed. The patients were assessed according to age, gender, complaints, tumor grade, localization, treatment method, recurrence, and functional outcomes.

Results: There were 85 (88.5\%) benign and 11 (11.5\%) malign tumors. Pain and swelling were evident in all malign tumors. Of the benign lesions, 57 had pain, and 19 had swelling accompanied by deformity. The malign and benign tumors of the radius were also detected in the second and third decades. The most common benign and malignant tumors were giant cell tumors ( $n=29,30.2 \%)$ and Ewing sarcoma $(n=6,6.2 \%)$. Fifty-six of 85 (65.8\%) benign lesions and 7 of 11 (63.6\%) malign lesions were located of the distal radius. The MSTS scores were $27.6 \pm 1.72$ and $24.5 \pm 1.77$ for benign and malign lesions, respectively. Local recurrence has occurred in three giant cell tumors and one Ewing sarcoma.

Conclusion: This study represents that curettage remains the feasible and first choice for benign lesions of the radius. Although the anatomy of the forearm is complex, limb-salvage surgery is possible with vascularized fibular autograft in malignant tumors.
\end{abstract}

Keywords: Radius; primary bone tumor; benign lesion; sarcoma

Corresponding Author*: Omer Sofulu, Marmara University, Faculty of Medicine, Department of Orthopaedic Surgery and Traumatology, Istanbul/TURKEY E-mail: omersofulu@gmail.com

ORCID: 0000-0002-5210-224X

Recevied: 23.08.2021 accepted: 18.10.2021

Doi: $10.18663 /$ tjcl.986379 


\section{Öz}

Amaç: Bu çalışmada, üçüncü basamak bir ortopedik onkoloji merkezinde radius primer kemik tümörü tanısı opere edilen hastaların insidansı, cerrahi tedavisi, histolojik ve anatomik dağılımlarının değerlendirilmesi amaçlanmıştır.

Gereç ve Yöntemler: Onyedi yıllık (2003-2020) zaman aralığında radius kemik tümörü tanısı ile merkezimize başvuran toplam 96 hasta ( 37 kadın, 59 erkek ) incelendi. Hastalar yaş, cinsiyet, şikayetler, tümör derecesi, lokalizasyon, tedavi yöntemi, nüks ve fonksiyonel sonuçlara göre değerlendirildi.

Bulgular: Çalışmamızda $85(\% 88,5)$ benign ve $11(\% 11,5)$ malign tümör vardı. Tüm malign tümörlerde ağrı ve şişlik belirgindi. Benign lezyonlardan 57'sinde ağrı, 19'unda deformitenin de eşlik ettiği şişlik vardı. Radiusun malign ve iyi huylu tümörleri ikinci ve üçüncü dekat yaş aralıklarında sık saptandı. En sık görülen benign ve malign tümörler dev hücreli tümörler ( $n=29, \% 30,2)$ ve Ewing sarkomu $(n=6, \% 6,2)$ idi. 85 benign lezyonun 56'sı $(\% 65,8)$ ve 11 malign lezyondan 7'si $(\% 63,6)$ distal radiusta yerleşimliydi. MSTS skorları benign ve malign lezyonlar için sırasıyla $27.6 \pm 1.72$ ve $24.5 \pm 1.77$ idi. Üç dev hücreli tümörde ve bir Ewing sarkomu hastasında lokal nüks meydana geldi.

Sonuç: Bu çalışma, radiusun benign lezyonları için küretajın uygulanabilir ve ilk seçenek olmaya devam ettiğini göstermektedir. Anatomik özellikleri karmaşık olsa da malign tümörlerde geniş cerrahi rezeksiyon ve vaskülerize fibula grefti ile ekstremite koruyucu cerrahi mümkündür.

Anahtar kelimeler: Radius; primer kemik tümörü; benign lezyon; sarkom

\section{Introduction}

The distribution of bone tumors in the skeletal system may vary. Bone tumors localizing to the radius are rare. [1]. Literature has shown that radius involvement constitutes 1.8 $\%$ to $3.7 \%$ of primary bone tumors [1,2]. Although the tumors of this region are primarily benign, malignant tumors have been associated with serious morbidity and mortality rate [3]. Large case series of distal radius localization of giant cell tumor (GCT) has been reported in the literature [4]. However, to our knowledge, there is no study presenting bone tumors located in all parts of the radius in a single study.

Various treatment modalities including, biological or endoprosthetic replacement procedures, have been described [4]. Previously, intralesional or marginal resection, curettage and packing with auto or allograft, and cementing methods were reported for benign bone tumors $[5,6]$. On the other hand, wide surgical margins are required for limb salvage surgery in malignant bone tumors [3]. Resection with wide surgical margins remains a challenge for surgeons in this unique anatomical site. However, the biological reconstructions performed in the forearm are promising [7].

The current study aimed to investigate the incidence of primary bone tumors of the radius and evaluate their clinical, oncological, and functional outcomes in a tertiary musculoskeletal tumor referral center.

\section{Material and Methods}

This study was granted by the local Ethics Committee (09.2019.1034) and conducted in accordance with the principles of the Declaration of Helsinki. One hundred nineteen patients operated with bone tumors of the radius in our center between 2003 and 2020 were reviewed retrospectively. Patients diagnosed with multiple myeloma $(n=3)$ and metastatic lesions (14) were excluded. In addition, six patients who did not attend regular follow-up were excluded. We have determined 96 cases who operated with primary bone tumor and tumor-like lesions of the radius. Patients followed up radiologically in the outpatient clinic were not included in the study.

The routine chemotherapy treatment protocol was IE-VAC (ifosfamide, epirubicin, vincristine, adriamycin, cisplatin) for Ewing sarcoma patients. On the other hand, osteosarcoma patients received preoperative (neoadjuvant) and postoperative (adjuvant) chemotherapy, including epirubicin, cisplatin, ifosfamide at the same center.

Data was collected from our hospital records, patient archiving and communication systems (PACS). The following variables were recorded; age and gender, tumor type, localization, application complaint, tumor grade according to Enneking classification [8], surgical methods, and recurrence rates.

The complaints of the patients are categorized as pain, 
swelling, and deformity. Localization of the tumor was classified as proximal, mid-diaphysis, and distal third of the radius. The clinical follow-up of the patients was performed weekly for the first month, every month for the first three months, every three months for the first year, every six months for the next year, and annually after that. Functional outcomes were evaluated according to the Musculoskeletal Tumor Society System (MSTS).

Descriptive analyses were presented using means, medians, standard deviations, lowest and highest values, or proportions. All calculations were performed using SPSS 21 software (IBM Corporation, Armonk, NY, USA).

\section{Results}

The mean follow-up of the study was 80 months (range 16148 months). There were 37 (38.5\%) female and 59 (61.5\%) male patients with a mean age of $26.7 \pm 13.5$ (range $8-57$ ). The mean age of the males was $26.9 \pm 9.7$ (range $8-48$ ), and the mean age of the female was $26.5 \pm 18.03$ (range 11-57). Lesions were located on the right side in 61 (63.5\%) patients and on the left side in 35 (36.5\%) patients. Benign tumor and tumorlike lesions of the radius constituted $88.5 \%(n=85)$, and malign lesions were $11.5 \%(n=11)$ (Table 1$)$. The most commonly involved site was the distal radius. Fifty-six of 85 (65.8\%) benign lesions and 7 of 11 (63.6\%) malign lesions were located of the distal radius. The second most common involvement was 16 (18.8\%) and 2 (18.1\%) for diaphyseal benign and malignant lesions, respectively.

\begin{tabular}{|c|c|c|}
\hline Diagnosis & & Patients [n(\%)] \\
\hline \multirow[t]{9}{*}{ Benign } & & $85(88.5 \%)$ \\
\hline & Giant cell tumor & $29(30.2 \%)$ \\
\hline & Aneurysmal bone cyst & $18(18.7 \%)$ \\
\hline & Osteochondroma & $9(9.3 \%)$ \\
\hline & Unicameral bone cyst & $9(9.3 \%)$ \\
\hline & Enchondroma & $7(7.2 \%)$ \\
\hline & Osteoblastoma & $7(7.2 \%)$ \\
\hline & Osteoid osteoma & $5(5.2 \%)$ \\
\hline & Desmoid tumor & $1(1.1 \%)$ \\
\hline \multirow[t]{4}{*}{ Malign } & & $11(11.5 \%)$ \\
\hline & Ewing sarcoma & $6(6.2 \%)$ \\
\hline & Osteosarcoma & $3(3.1 \%)$ \\
\hline & Chondrosarcoma & $2(2.1 \%)$ \\
\hline Total & & $96(100 \%)$ \\
\hline
\end{tabular}

The vast majority of the malign tumor of the radius ( 9 of 11) had developed in the 10 to 20-year group in our study (Table 2 ). Besides, the vast majority of the benign tumors (42 of 85 ) had developed in the 20 to 60-year group. We did not detect any malignant tumors under the age of 10 or over 60 years.

\begin{tabular}{|c|c|c|c|c|c|}
\hline \multicolumn{6}{|c|}{ Age group } \\
\hline Lesions & $<10$ & 10 to 20 & 20 to 60 & $>60$ & Total \\
\hline Benign & 2 & 32 & 42 & 9 & 85 \\
\hline Malign & 0 & 9 & 2 & 0 & 11 \\
\hline Total & 2 & 41 & 44 & 9 & 96 \\
\hline
\end{tabular}

Pain and swelling were evident in all malign tumors. Of the benign lesions, 57 had pain, and 19 had swelling accompanied by deformity. Although swelling and deformity were related to distal involvement, all diaphyseal lesions were admitted with pain. A patient with diaphyseal Ewing sarcoma was presented with a pathological fracture at 19th month.

Giant cell tumor was the most frequently diagnosed primary benign bone tumor of the radius $n=29$ (30.2\%), followed by aneurysmal bone cyst $n=18$ (18.7\%). For malign bone tumors, six patients had Ewing sarcoma (6.2\%), 3 had osteosarcoma (3.1\%), and 2 had chondrosarcoma (2.1\%). Of the 85 cases of benign bone tumors, 60 were Enneking stage 3 lesions. For malign lesions, eight lesions were stage IIA, two patients were IIB, and a patient with distant metastasis was stage III at the initial presentation (Table 3 ).

\begin{tabular}{|c|c|}
\hline Enneking classification & n (\%) \\
\hline 1 & $9(9.3 \%)$ \\
\hline 2 & $16(16.6 \%)$ \\
\hline 3 & $60(62.5 \%)$ \\
\hline $\mathrm{IA}$ & $0(0 \%)$ \\
\hline IB & $0(0 \%)$ \\
\hline$\| A$ & $8(8.3 \%)$ \\
\hline IIB & $2(2.1 \%)$ \\
\hline III & $1(1.1 \%)$ \\
\hline Total & $96(100 \%)$ \\
\hline
\end{tabular}

In benign tumors of the radius, the most commonly applied treatment method was curettage and PMMA (62 of 85 cases $72.9 \%)$, followed by marginal resection in 14 patients (16.4\%). Five patients (5.2\%) underwent curettage followed by graft packing (Figure 1). Giant cell tumor was the most common indication for curettage and PMMA (29 of 62 patients). Nine osteochondroma patients underwent marginal resection. Wide resection and vascularized fibular graft were performed for 6 Ewing sarcoma, three osteosarcomas, and a chondrosarcoma patient (Table 4). Free vascularized fibular head grafting was applied in 7 patients as an osteoarticular autograft (Figure 2). 
Osteosynthesis with plate screw or percutaneous pinning was performed in all malignant patients and 39 benign patients.

\begin{tabular}{|c|c|c|}
\hline Table 2 & ycal methods accordıng to tnne & classification \\
\hline Stage & Treatment & $\begin{array}{l}\text { Patients } \\
{[\mathrm{n}(\%)]}\end{array}$ \\
\hline Stage1 & & $9(9.3 \%)$ \\
\hline & Excision & $4(4.1 \%)$ \\
\hline & Resection & $3(3.1 \%)$ \\
\hline & Curettage plus graft packing & $2(2.1 \%)$ \\
\hline Stage 2 & & $16(16.6 \%)$ \\
\hline & Curettage plus PMMA & $8(8.3 \%)$ \\
\hline & Resection & $5(5.2 \%)$ \\
\hline & Curettage plus graft packing & $3(3.1 \%)$ \\
\hline Stage 3 & & $60(62.5 \%)$ \\
\hline & Curettage plus PMMA & $54(56.3 \%)$ \\
\hline & Resection & $6(6.2 \%)$ \\
\hline Stage IA & & 0 \\
\hline Stage IB & & 0 \\
\hline Stage IIA & & $8(8.3 \%)$ \\
\hline & Wide resection plus vascularized fibula & $7(7.2 \%)$ \\
\hline & Wide resection plus strut graft & $1(1.1 \%)$ \\
\hline Stage IIB & & $2(2.1 \%)$ \\
\hline & Wide resection plus vascularized fibula & $2(2.1 \%)$ \\
\hline Stage III & & $1(1.1 \%)$ \\
\hline & Wide resection plus vascularized fibula & $1(1.1 \%)$ \\
\hline Abbreviatic & ion: PMMA, polymethylmethacrylate & \\
\hline
\end{tabular}

A

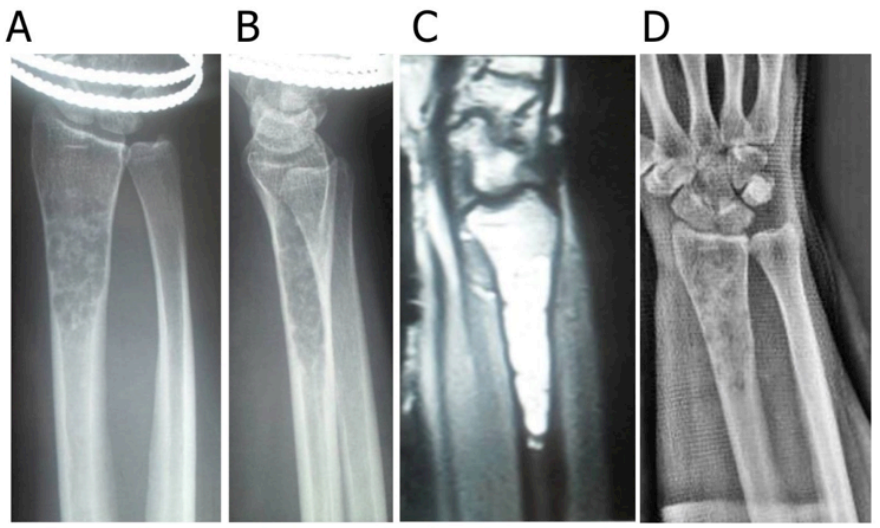

Figure 1: A 24-year-old female with distal radius enchondroma: $a, b)$ preoperative plain radiograph, c) preoperative magnetic resonance image, d) the patient underwent curettage followed by graft packing.

Overall mean MSTS score was $27.2 \pm 1.99$. The MSTS scores were $27.6 \pm 1.72$ and $24.5 \pm 1.77$ for benign and malign lesions, respectively. In malignant bone tumors that underwent wide resection and free vascularized fibular head graft, good functional outcomes were achieved. The postoperative splint was applied to all malignant tumors and 75 out of 85 benign tumors.
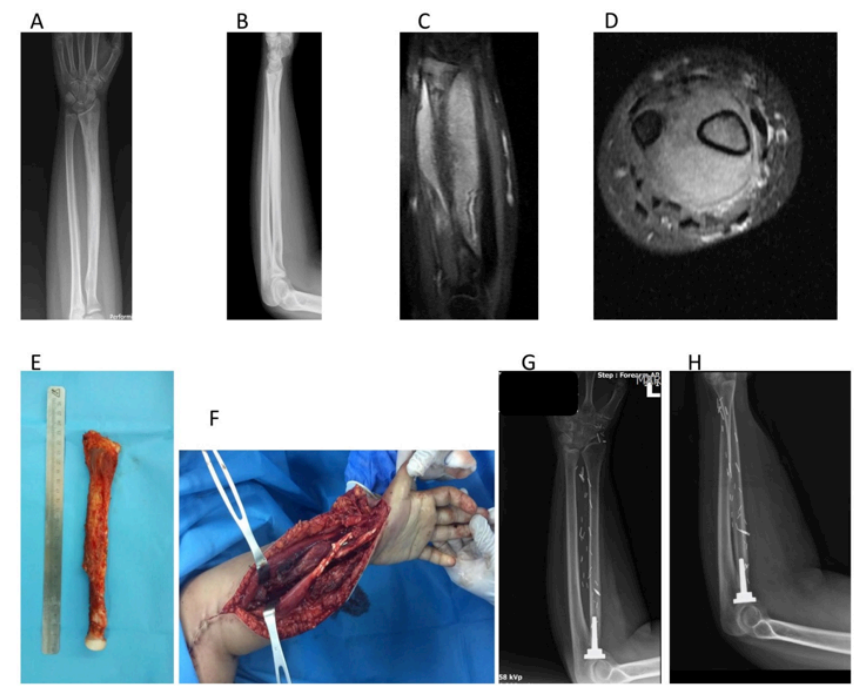

Figure 2: (a,b) Preoperative plain radiograph of a 16-year-old female with radius diaphyseal Ewing sarcoma, (c,d) MR images showed significant soft tissue extension, $(\mathrm{e}, \mathrm{f})$ the patient had wide resection and biological reconstruction with osteoarticular vascularized fibular graft, a radial head prosthesis was also applied, (g,h) follow-up radiographs.

Local recurrence was detected in a patient with stage III diaphyseal Ewing sarcoma at a 42-month follow-up. This patient underwent seconder amputation. Limb salvage was achieved in 10 of 11 malignant bone tumors (90.9\%). Three patients $(10.3 \%)$ with giant cell tumors of the distal radius was recurrence at mean 76 years (range 54 to 93) follow-up and underwent re-curettage and PMMA application. At the time of the study, 72 patients were alive with no evidence of disease (NED), and seven patients died of disease (DOD), and 17 patients died for other causes.

\section{Discussion}

Bone tumors of the radius are rare [1]. There are many studies in the literature on giant cell tumors of the distal radius $[4,5,6]$. However, to the best of our knowledge, there is no study presenting all primary bone tumors and tumor-like lesions of the radius bone in the same study. The current study presents an extensive record of radius-located tumors from a tertiary musculoskeletal oncology care center. The most important findings of our study were that; benign and malign tumors of radius were localized in the distal part of the bone, the most common benign primary tumors were giant cell tumor, curettage plus PMMA was the most common surgical application for benign lesions, malign lesions of radius were treated successfully with wide resection plus free vascularized fibular head autograft, and we did not detect any malignant tumors under the age of 10 or over the age of 60 years in our study.

In 2005, Daecke et al. published twenty-seven-year data and 
reported that 39 patients were diagnosed with osteosarcoma in hand and forearm [9]. Ozturk et al. reported their large bone tumor series and identified only $1.8 \%$ radius bone tumor involvement [1]. The current study has confirmed the rarity of radius bone tumors. Despite the scarcity of localization of this region in the literature, our study is important in showing the experience of a tertiary tumor center.

Previous studies have shown that patients with radius benign tumors are detected in the second to third decades $[10,11]$. Pradhan et al. reported that the average age of patients with forearm sarcomas was 30 years [3]. Some studies have reported that for an older age group, patients with osteosarcoma of the upper distal extremities [12]. The mean age of patients in this study was 26.7 years (range $8-57$ ). Consistent with the literature our malign and benign tumors of the radius were also detected in the second and third decades.

There are many epidemiological study records for giant cell tumors of the distal radius $[4,5,6]$. Crowe et al. published $17-$ year data of their clinic and reported that 7 of 11 aneurysmal bone cysts were localized forearm and wrist [13]. Pradhan et al. published 27-year data including 1650 patients with osteosarcoma, 35 patients $(2 \%)$ had in the distal upper extremity [3]. Our study's most common benign bone tumor of the radius was giant cell tumors and aneurysmal bone cyst. Six patients had Ewing sarcoma for malign bone tumors, three had osteosarcoma, and two had chondrosarcoma. Most of the previous studies focused on aggressive benign and malign lesions of the radius [7]. Giant cell tumors have occurred in the distal radius in approximately $10 \%$ of cases (range $8 \%$ to $13 \%$ ) $[5,6,11]$. Pradhan et al. reported forearm osteosarcomas and detected ten distal and one midshaft radius involvement [3]. The most commonly involved site in our study was the distal radius. Fifty-six of 85 benign lesions and 7 of 11 malign lesions were located of the distal radius. The second most common involvement was $16(18.8 \%)$ and 2 (18.1\%) for diaphyseal benign and malignant lesions, respectively.

Primary radius tumors may present with different clinical complaints. In our study, pain and swelling were evident all malign tumors. Of the benign lesions, 57 had pain, and 19 had swelling accompanied by deformity. Although swelling and deformity were related to distal involvement, all diaphyseal lesions were admitted with pain. Salunke et al. observed pathological fractures in 6 of 25 GCT patients [14]. However, no fracture was observed in benign tumors in our series. A patient with diaphyseal Ewing sarcoma was presented with a pathological fracture. This may be attributed to the early admission of these patients and the short prodromal period.

Qi et al. reported a rate of Enneking stage 3 lesions in a 12 GCT of $100 \%$ in their study [6]. Salunke et al. reported that $84 \%$ of benign lesions were diagnosed at stage 3 [14]. In the current study, $70.5 \%$ of benign lesions were stage 3 lesions, and the majority of malignant lesions were Enneking stage IIA (8 of 11). The most commonly applied treatment method was curettage and PMMA (62 of 85 cases $72.9 \%$ ), followed by marginal resection in 14 patients (16.4\%). Giant cell tumor was the most common indication for curettage and PMMA (29 of 62 patients). Various treatment modalities, including en-bloc resection, vascularized fibular graft, non-vascularized fibular graft, and ulnar translocation, have been described in the literature $[6,10,11]$. Although stage 3 lesions were the majority in our series, we were able to treat most of our patients with curettage and PMMA.

Free vascularized fibular grafts are useful to restore bone defects after tumor resection because of their mechanical support [15]. Innocenti et al. reported that vascularized fibular head transfer provides a reliable and durable reconstruction of the distal radius in malignant distal radius tumors [16]. Resection with wide surgical margins remains a challenge for surgeons in this unique anatomical site. Tumor-free margins should be obtained by wide surgical resection. Although the anatomy of the forearm is complex, limb-salvage surgery is possible with vascularized fibular autograft in malignant tumors [7]. Overall mean MSTS score of our cohort was $27.2 \pm 1.99$. The MSTS scores were $27.6 \pm 1.72$ and $24.5 \pm 1.77$ for benign and malign lesions, respectively. Consistent with the literature, we also achieved successful results with free vascularized fibular head grafts.

The local recurrence rate of GCT of the radius has been reported that $3 \%$ to $28 \%$ in the literature [11]. Crowe et al. detected recurrence 1 of 11 patients with aneurysmal bone cysts [13]. The local recurrence rate of benign tumors was $10.3 \%$ in our series. On the other hand, Pradhan et al. reported a $4 \%$ local recurrence rate of osteosarcoma of the upper distal extremities [3]. Local recurrence was detected in a patient with stage III diaphyseal Ewing sarcoma at 42-month follow-up in our series. This patient underwent seconder amputation. Limb salvage was achieved in 10 of 11 malignant bone tumors.

The limitation of this study is a small sample size and retrospective design. Lack of clinical, oncological, and functional outcomes are weakness. So a multicenter study with a comparison group would be recommended for future studies. 


\section{Conclusion}

Primary bone tumors and tumor-like lesions of the radius are rare. In the current study, the most common benign tumor was GCT, the most common malignant tumor was Ewing sarcoma. Benign and malign tumors of radius were localized in the distal part of the bone. Pain and swelling were the two primary complaints of patients. The vast majority of primary bone tumors of radius developed in the second and third decades. Curettage plus PMMA was the most common surgical application for benign lesions. Malign lesions of radius were treated successfully with wide resection plus free vascularized fibular head autograft. When compared with other published studies, we believe that our study would contribute to the literature.

\section{Declaration of conflict of interest}

The authors received no financial support for the research. There is no conflict of interest

\section{References}

1. Öztürk R, Arıkan ŞM, Bulut EK, et al. Distribution and evaluation of bone and soft tissue tumors operated in a tertiary care center. Acta Orthop Traumatol Turc 2019; 53: 189-94.

2. Bergovec, Kubat $O$, Smerdelj $M$, et al. Epidemiology of musculoskeletal tumors in a national referral orthopedic department. A study of 3482 cases. Cancer epidemiol 2015; 39 : 298-302.

3. Pradhan A, Reddy KIA, Grimer RJ, et al. Osteosarcomas in the upper distal extremities: Are their oncological outcomes similar to other sites? Eur J Surg Oncol 2015; 41: 407-12.

4. Liu YP, Li KH, Sun BH Which treatment is the best for giant cell tumors of the distal radius? A meta-analysis. Clin Orthop Relat Res 2012; 470: 2886-94

5. Mozaffarian K, Modjallal M, Vosoughi AR Treatment of giant cell tumor of distal radius with limited soft tissue invasion: curettage and cementing versus wide excision. J Orthop Sci 2018; 23: 174-9.

6. Qi DW, Wang P, Ye ZM, et al. Clinical and radiographic results of reconstruction with fibular autograft for distal radius giant cell tumor. Orthop Surg 2016; 8: 196-204.
7. Muramatsu K, Ihara K, Yoshida K, et al. T Musculoskeletal sarcomas in the forearm and hand: standard treatment and microsurgical reconstruction for limb salvage. Anticancer Res 2013; 33: 4175-82.

8. Enneking WF, Spanier SS, Goodman MA: The classic: A system for the surgical staging of musculoskeletal sarcoma. Clin Orthop Relat Res. 2003; 415: 4-18.

9. Daecke W, Bielack S, Martini AK, et al. Osteosarcoma of the hand and forearm: experience of the Cooperative Osteosarcoma Study Group. Ann Surg Oncol 2005; 12: 322-31.

10. Zou C, Lin T, Wang B, et al. Managements of giant cell tumor within the distal radius: a retrospective study of 58 cases from a single center. J Bone Oncol 2019; 14: 100211.

11. Kang L, Manoso MW, Boland PJ. Features of grade 3 giant cell tumors of the distal radius associated with successful intralesional treatment J Hand Surg 2010; 35: 1850-7

12. Okada K, Wold LE, Beabout JW, et al. Osteosarcoma of the hand: a clinicopathologic study of 12 cases. Cancer 1993; 72: 719-25.

13. Crowe MM, Houdek MT, Moran SL, et al. Aneurysmal bone cysts of the hand, wrist, and forearm J Hand Surg 2015; 40: 2052-7.

14. Salunke AA, Chen $Y$, Chen $X$, et al. Does pathological fracture affect the rate of local recurrence in patients with a giant cell tumour of bone? A meta-analysis. Bone Joint J 2015; 97: 1566-71.

15. Germain MA, Mascard E, Dubousset J, et al. Free vascularized fibula and reconstruction of long bones in the child-our evolution. Microsurgery: Official Journal of the International Microsurgical Society and the European Federation of Societies for Microsurgery. 2007; 27: 415-9.

16. Innocenti $M$, Baldrighi $C$, Menichini $G$. Long term results of epiphyseal transplant in distal radius reconstruction in children. Handchir Mikrochir Plast Chir 2015; 47: 83-9. 